\title{
Surfacing Anger and Anxiety in Graduate Research Writing: A Prose Poetic Journey
}

\section{Maria Minerva P. Calimag, MD, MSc. (Clin. Epi.), PhD}

\begin{abstract}
Life writing is not only recording and reporting and repeating the lived story as known, as written by the subject; life writing is recoding and restorying and restoring the lived story as unknown, as unwritten by the subject.

-Carl Leggo, 2001[1]
\end{abstract}

\section{ABSTRACT}

Research writing evokes feelings of anger and anxiety even among graduate students. Feelings are an inseparable part of the human lived experience and are important to learning and decision making. Research anxiety is powerful but not impossible to overcome. Various affective, cognitive, linguistic, and pedagogical mitigating strategies can be employed. By simply acknowledging its existence, we lead our students in the direction of doing just that...towards a transformational mindset to overcome research anxiety. Written qualitatively in the hermeneutic strand, this paper explores the lived experience and collective portrayals of the phenomenon of graduate research writing anxiety using prose poetry. The main forms of poetry qualitative researchers create vary from data poems or transcription poems, research poems, and autoethnographic poetry. Autoethnographic poetry is created by the author through self-reflection

Maria Minerva P. Calimag, MD, MSc. (Clin. Epi.), PhD mpcalimag@ust.edu.ph

The Faculty of Medicine and Surgery, The Research Center for Social Science and Education and The Research Center for the Health Sciences, University of Santo Tomas, Manila, Philippines and writing to explore anecdotal and personal experiences and connect this autobiographical story to wider cultural, political, and social meanings and understandings. In this paper, the author writes from an emic perspective utilizing intertextual chaining to create an autoethnographic research prose poetry. The paper describes in rich detail, the dominant feelings about research writing anxiety and anger that surfaced from participants' narratives of their shared experience of research writing anxiety. Prose poetry is written in paragraphs rather than verse but contains the elements of poetry, such as poetic meter, language play, and a focus on images rather than narrative, plot, and character.

Key words: research writing anxiety, poemish (research) poetry, prose poetry, autoethnography, hermeneutics

\section{INTRODUCTION}

Research writing evokes feelings of anger and anxiety even among graduate students. Feelings are an inseparable part of the human lived experience and are important to learning and decision making. Research anxiety is powerful but not impossible to overcome. In 1975, Daly and Miller [2] introduced the concept of writing anxiety, also called writing apprehension. The term describes writing-specific anxiety which is situation and subject-specific. Individual difference is associated with tendencies of an individual to approach or avoid the situation because the writing is accompanied by a degree of perceived evaluation. Writing anxiety may occur if students are expected to write excellently. Students who suffer from writer's anxiety because they fear that judgment is personal 
rather than performance-based tend to shy away from the idea of writing overall, usually most pronounced in an academic setting.[2] "Writing anxiety" and "writer's block" are informal terms for a wide variety of apprehensive and pessimistic feelings about writing. These feelings may not be pervasive in a person's writing life. Hiortshoi [3] purports that the phenomenon of writing anxiety and writers' block are situational, explaining that obstacles are particularly common during times of transition - transitions to new writing roles or to new kinds of writing. Some situational possibilities include: writing in a new format, writing longer papers than before, writing for new audiences, writing about a new subject matter, writing about an abstract phenomenon, and writing in a foreign language.[4-7].Even students that see themselves as "good writers" or "capable writers" suffer from writing anxiety. They cannot make the leap from what is a natural discourse in their heads to the prescribed idea of organization posed by a new research genre, as in shifting from the quantitative to qualitative research.

\section{The Narrative}

I thought all the while that my position in the research community is secure until en route into a doctoral career in education, I found myself confronted with yet another dimension of research. Honed in the clear-cut, almost repetitious, and cyclical pattern of research in the hard sciences and its biases towards randomized, controlled trials, I made a $180^{\circ}$ turn and became absorbed with qualitative research: its varied facets, its startling twists and turns, and expanded my research endeavors into the realm of medical education. Suffering through post-positivist inertia, deciding what to include-and what to leave out-was not an easy task. My initial impulse was to include everything, perhaps apprehensive that I may not find the right words to express my thoughts again. I am still not able to completely abandon the numbers in favor of metaphors. I find myself straddling in the great abyss that is the quantitative-qualitative divide. My right brain wants to indulge in poetic discourse while my left brain wants to hang on to analytic discourse, borne out of my engagement in evidencebased medicine as a clinical epidemiologist.

When I decided to write my dissertation in the qualitative genre, I enrolled in a course on qualitative research. As part of our authentic assessment, I together with 10 of my classmates was required to write our own story of research anxiety. How do I write it? Angst-ridden I plunged myself into that part of me which I have not totally explored. Can I really write a literary piece about myself? I quickly wrote my story and handed it in with barely a second look. My first attempt resulted dismally into what our professor termed as "riddled" (my own perception of what he meant) "with incidentals." Words could not just be thrown down on paper and be called a story. Confronted with the need to re-write my story, bleary-eyed, sleep-deprived, hoping for inspiration and yearning for another cup of coffee, and maybe some nice chocolate-chip cookies, a dozen nagging, self-mocking thoughts echoing in my head, staring pathetically at the empty computer screen -imagining myself wand in hand like Hermione Granger of Harry Potter in the Sorcerer's Stone and saying "Wingardium Leviosa" [8]. Nothing happened... and my heart started to race, my hairs stand on ends, a feeling of cold wind blowing on my warm nape, and my mind whirling... one thousand words by weeks' end. Yes! I have all the signs and symptoms of anxiety...that's what I am going to write about-my writing experience in qualitative research. Pumping all my creative juices I settled, took a deep breath...I have no choice; I must write about it today-today is SUBMISSION DAY!

My experience of being a writer is of walking a constant tight rope between processing negative feedback and rejection and feeling good enough about my work to not give up completely. There have been extreme highs and extreme lows over the years, and I'm not expecting things to get any easier as time goes on - just different. Although I believe that I would never improve if I were not able to take on feedback from others, I also need to manage this process, so it doesn't overwhelm me. If I am not passionate about my work at least some of the time, then how can I expect anyone else to value what I am doing? So, how do I survive?

For as long as I can remember I have been interested in reading and writing. I am not sure of the exact reason I became so drawn to those subjects. I tend to think my mother had a large impact on me as she was a bibliophile. She had heaps of Reader's Digest in a cabinet, and I would literally devour all its contents whenever I had spare time. I used to write intensely. I excelled in English and writing courses all through school but did not view them as my best subjects. I was more interested in Science and Math (my parents' forte). I never thought I would wind up 
studying writing as closely as in this course and the experience is still giving me the creeps...the kind of anxiety that emerges occasionally in a writer's life: the kind of gut-wrenching, dizzying upheaval from within, that throws everything you think you know into doubt, the kind that scares you to the very core and into a spate of sudden, incomprehensible fright attacks. What will I write about?

The weeks past had been hell, my temper teetering on volatility. I cannot place myself in the frame of mind for writing, let alone write sentences to express my thoughts. I brainstormed, freewrote, and assembled the pieces together, nebulous, and amorphous at first; disorganized and rambling...erasing and rewriting those dreadful and shameless words... blindly searching in the air for images in words. At first, I wrote my ideas in short phrases, then sentences just so I will not forget them. Then, I started to feel a little better because as I wrote I almost felt liberated-bit by bit-I was finally able to get all my emotions out. All I wanted was someone to listen and not critique back. The paper I was writing on provided that for me. Then, another realization-writing, the very thing that triggered my fear is providing the antidote for it-a catharsis. Before I was able to put anything down on paper, I sat in my room wanting to pound my head against the wall and eventually make myself literally sick over the situation. Instead, I now have a safe and healthy way to release my tension... when all that is left is writing; writing is all that is left. As a research adviser, I had always told my advisees to write about something new-as I write now, I can hear myself following my own counsel. The more experience we have with new things the better off we are. For our data, I, and my fellow graduate students in qualitative research each wrote our own story about anxiety and anger in research writing. Using our narratives as data, all of us ended up writing about research writing anxiety in the qualitative genre based on our own understanding and appreciation of the phenomenon using our own interpretive ways.

\section{Research Design}

Writing qualitatively in the hermeneutic strand by Heidegger,[9], I approached the topic about how I made meaning from an emic perspective as I am myself immersed in the lived experience of graduate research writing anxiety creatively using prose poetry to represent our collective portrayals of the phenomenon.
Lahman, et al, [10] in their paper "ish: How to Write Poemish (Research) Poetry" described research poetry thus: "poemish representations may be said to be research representations characterized by features of poetry and an effort to blend the aesthetics of poetry and science of research into something which may be said to be poem-like, ish, or poemish."

Prose poetry is written like prose, in paragraphs rather than verse, but contains the characteristics of poetry, such as poetic meter, language play, and a focus on images rather than narrative, plot, and character. Fitzpatrick and Fitzpatrick [11] portrayed the role of poetry in their research writing. KATIE: "poetry is, actually, one of the things that keeps me alive in the academy. Not in the biological sense, but in the sense of having life, inside, in keeping alight and alive; staying alive to what is important and what holds." ESTHER: "poetry enables me to get to the essence of the matter, to the embodied response that I have to a particular thing under investigation and, through the writing of poetry, to make sense of it in a new way." The main forms of poetry qualitative researchers create continue to be data poems or transcription poems eg, Glesne [12], which are poems researchers create with data from interview transcripts and personal narratives; research poems, which the researcher creates about the research experience; and auto-ethnographic poetry, created by the author through self-reflection and writing to explore anecdotal and personal experience and connect this autobiographical story to wider cultural, political, social meanings, and understandings. This paper adopts autoethnography as its research design [13]. I wrote from an emic perspective utilizing intertextual chaining to create an autoethnographic research prose poetry. The paper holistically describes in rich detail, the dominant feelings about research writing anxiety and anger that surfaced from the narratives of our shared experience, where I, the researcher, was featured as a full member of the community or experience being studied.[14,15] The ethnographic method herein adopted focused on evoking the experience with emotional richness through narratives before facilitating an analysis. The narratives were seen as the basis, method, and eventual result of autoethnographic research, albeit alternatively represented in the form of autoethnographic prose poetry. This is our story describing exactly how we felt, and to describe it any other way would be to invalidate our experiences and feelings. 


\section{Thematic Analysis}

Analysis using the Owen's [16] three criteria for thematic identification was used as a framework to address the basic research question What are the elements affecting the development of anger and anxiety among graduate students faced with the required research writing? Protocols were read many times to identify Owen's criteria for recurrence of ideas within the narrative data (ideas that have the same meaning but different wording), repetition (the existence of the same ideas using the same wording), and forcefulness (verbal or nonverbal cues that reinforce a concept). Thematic identification was performed on both intrathematic and interthematic levels. The themes were isolated on an individual basis (intrathematic) and then compared on a project-wide basis (interthematic), allowing for the development of major content themes encountered in the narrative protocols. The major themes isolated were suggestive of the elements of anxiety and anger that we experienced while undergoing graduate research writing. Most themes were identified because of recurrence. Repetition was recognized in a smaller portion of the participant narratives but considerably more so than forcefulness.

\section{Findings}

The list of responses drawn (see Table I) showed a variety of metaphorical representations. The

Table 1. Stages of anger and anxiety during the Graduate research writing experience

\begin{tabular}{|c|c|c|}
\hline Themes & Associated Meanings & Metaphors \\
\hline \multirow[t]{3}{*}{ 1. Paralysis } & a. Feeling of inaction & 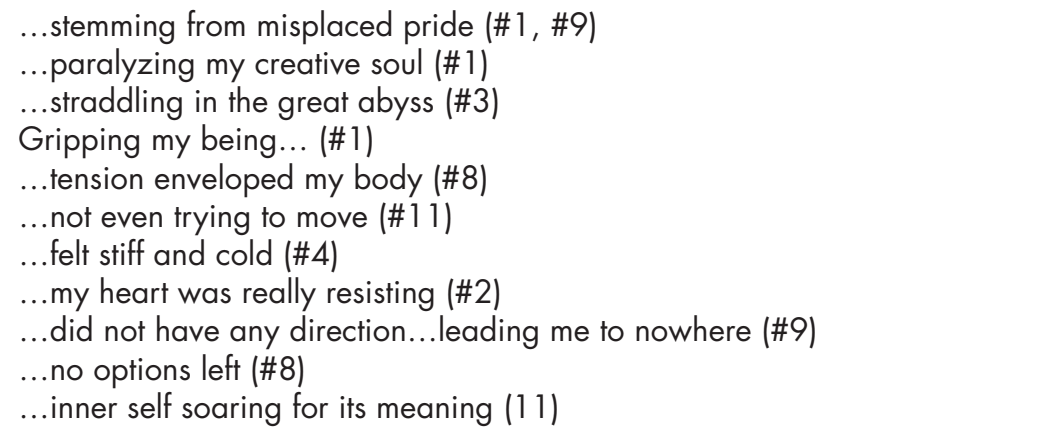 \\
\hline & b. Feeling of inadequacy & 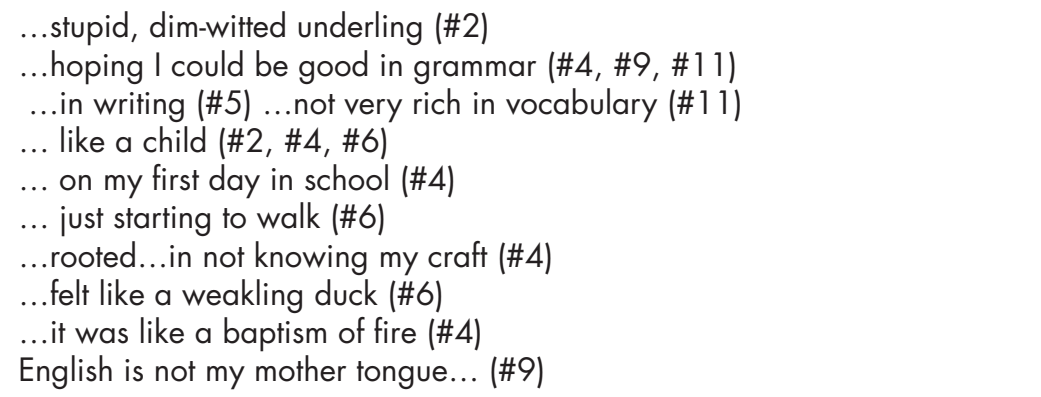 \\
\hline & $\begin{array}{l}\text { c. Feeling of } \\
\text { indeterminacy }\end{array}$ & $\begin{array}{l}\text {...totally disoriented in many ways (\#5) } \\
\text {... all sorts of uncertainties plugged my mind (\#8) } \\
\text {...had gone in the wind....in so many directions (\#6) } \\
\text {...that part of me which I have not totally explored (\#3) } \\
\text {... saying exactly the opposite of what I was feeling (\#4) } \\
\text {...the battle was there... but enemy nowhere to find (\#11) } \\
\text {...could never tie up loose ends (\#5) } \\
\text {... it seemed so dark though the sun was shining brightly (\#2) }\end{array}$ \\
\hline $\begin{array}{l}\text { 2. Procrastination } \\
\text { and Progression }\end{array}$ & a. Feeling of hesitancy & 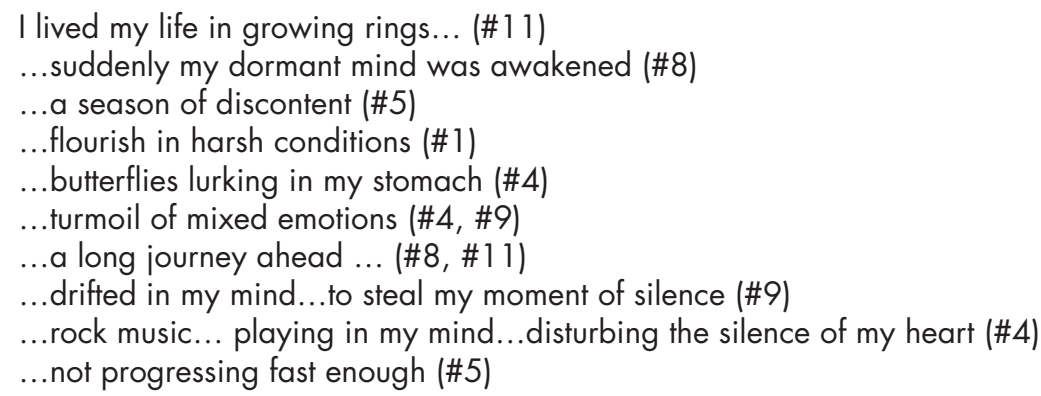 \\
\hline
\end{tabular}


Table 1. Stages of anger and anxiety during the Graduate research writing experience

\begin{tabular}{|c|c|c|}
\hline Themes & Associated Meanings & Metaphors \\
\hline & $\begin{array}{l}\text { b. Feeling of } \\
\text { helplessness }\end{array}$ & 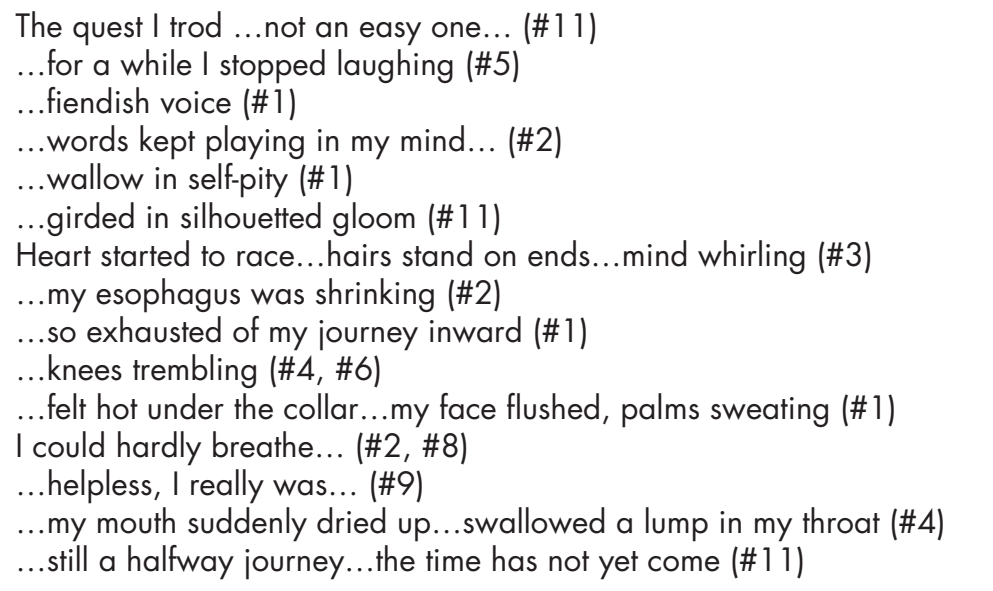 \\
\hline & $\begin{array}{l}\text { c. Feeling of } \\
\text { hopelessness }\end{array}$ & 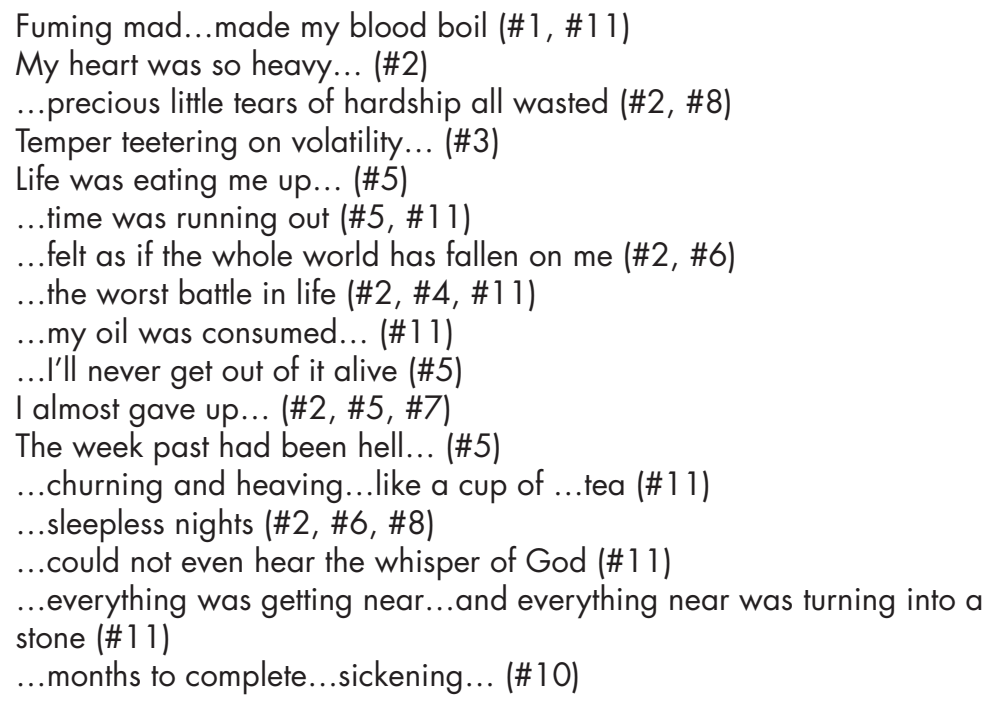 \\
\hline \multirow[t]{3}{*}{$\begin{array}{l}\text { 3. Pinnacle and } \\
\text { Plateau }\end{array}$} & a. Feeling of submission & $\begin{array}{l}\text { Letting go... (\#1) } \\
\text { Look in and study myself...I took a peek (\#3) } \\
\ldots \text {.emptying myself was necessary (\#9) } \\
\ldots \text {. detach myself from all (\#10) } \\
\text { I surrendered... better with the help of others (\#1) } \\
\text { I learned to accept the pain... (\#2) } \\
\ldots \text {. renounce my pride....and transcend all (\#1 1) } \\
\text {... a mind conditioning... }\end{array}$ \\
\hline & b. Feeling of sufficiency & $\begin{array}{l}\text {...take stock of my predicament (\#1) } \\
\text {...malleable and tentative...constantly willing to change (\#3) } \\
\text { As a tiger...get out... unscathed (\#4) } \\
\text { Face the battle... (\#2) } \\
\text {...take the bull by its horns (\#1) } \\
\text {... handle my anger right (\#11) }\end{array}$ \\
\hline & c. Feeling of surmounting & 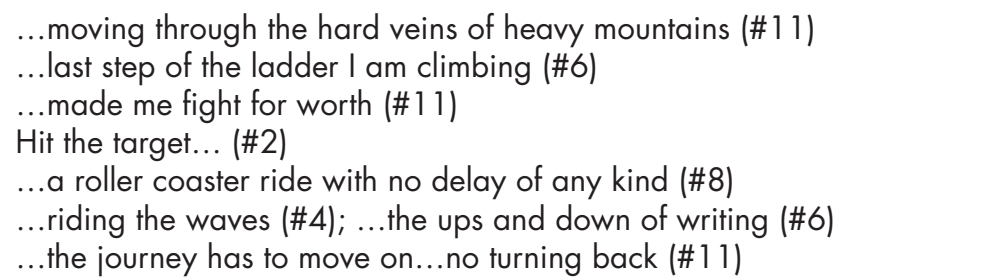 \\
\hline
\end{tabular}


Table 1. Stages of anger and anxiety during the Graduate research writing experience

\begin{tabular}{|c|c|c|}
\hline Themes & Associated Meanings & Metaphors \\
\hline \multirow[t]{3}{*}{ 4. Plunge } & a. Feeling of relief & 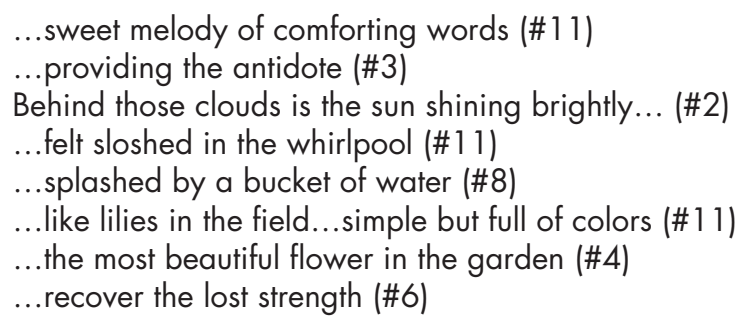 \\
\hline & b. Feeling of release & $\begin{array}{l}\text { My life would be shining again... (\#2) } \\
\ldots \text {..smooth sailing all along (\#1) } \\
\text { Memories...like starlight (\#5) } \\
\text {...the gloomy side made the other side brighter (\#2) } \\
\text {...to embrace a different ethos (\#3) } \\
\text {... chance to grow a soul (\#5) } \\
\text {... as if I peeped a bit of heaven (\#1 1) } \\
\text {... all the worries led...to a deeper joy (\#2) }\end{array}$ \\
\hline & c. Feeling of resoluteness & 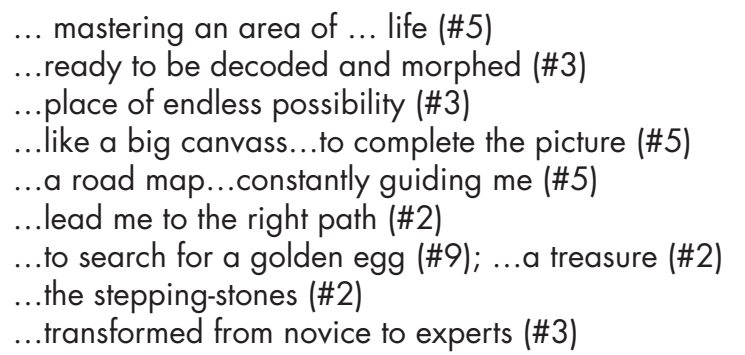 \\
\hline
\end{tabular}

associated meanings have been culled from narrative portrayals by the graduate students. By providing "intertextual links" their collective portrayals for each of the thematic clusters are created through "intertextual chaining".[7] What evolved was poetic prose about the representations, roots, and resolution of research writing anxiety among graduate students.

\section{Representations}

The four thematic clusters evolved were Paralysis, Procrastination and Progression, Pinnacle and Plateau, and Plunge, much like the slow-moving onset, the sloping prelude, the summiting climax, and the sliding descent characteristic of poetry (see Figure 1). Each cluster was further subdivided into three subclusters descriptive of the emotions evoked during the experience.

The PARALYSIS PHASE echoed feelings of inaction, inadequacy, and indeterminacy. "Research writing was something gripping my being, probably... stemming from misplaced pride...no options left as if...straddling in the great abyss...paralyzing my creative soul. Tension enveloped my body...my inner self soaring for its meaning...my heart resisting... stiff and cold; trying to move, but... did not have any direction...leading me to nowhere. I...felt like a child... a stupid, dim-witted underling ... a weakling duck... just starting to walk...on my first day in school. Since English is not my mother tongue...I hoped...that I could be good in writing... in grammar...rich in vocabulary. It was like a baptism of fire...rooted...in not knowing my craft. It was like entering...that part of me which I have not totally explored,... all sorts of uncertainties plugged my mind, there were times that I was...saying exactly the opposite of what I was feeling, ... it seemed so dark though the sun was shining brightly,...the battle was there... but enemy nowhere to find, all my efforts... had gone with the wind... in so many directions... disoriented... it seems that I... could never tie up the...loose ends."

As ifegged on by forces unseen, the journey takes an uphill course and the PROCRASTINATION AND PROGRESSION PHASE reverberated with feelings of hesitancy, helplessness, and hopelessness. "I lived my life in growing rings... with...butterflies lurking in my stomach...rock music...playing in my mind...stealing and 


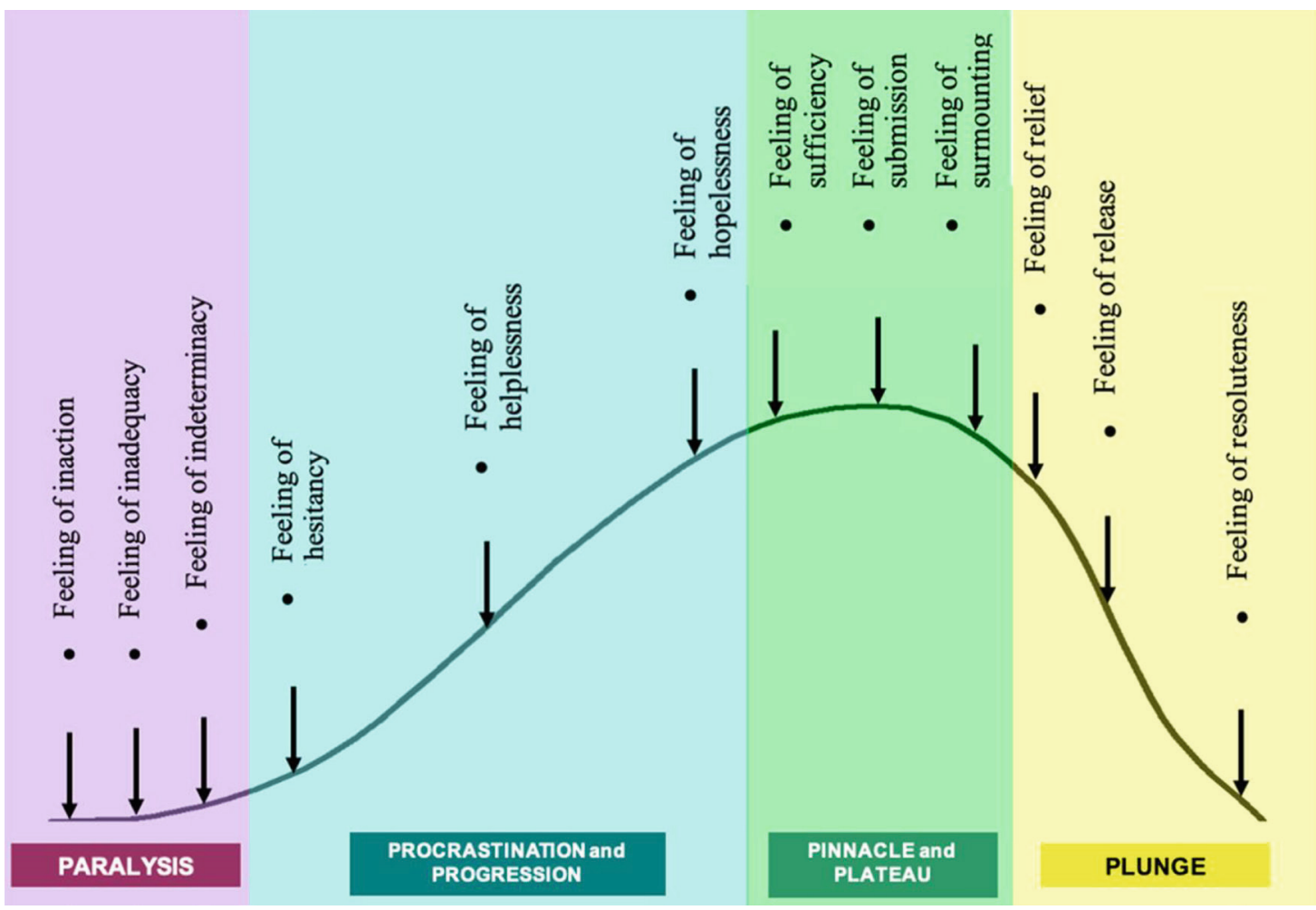

Figure 1. Representation of the sloping rise and fall of emotions in the lived experience of research writing anxiety.

disturbing the silence of my heart. My dormant mind was awakened...l enter ...a season of discontent, a...turmoil of mixed emotions engulfing me, I...flourish in harsh condition, yet I face... a long journey ahead and I am not progressing fast enough. For a while I stopped laughing...girded in silhouetted gloom... a fiendish voice... whispered at me to wallow in self-pity. I felt hot under the collar...my face flushed, palms sweating...my heart started to race...hairs stand on ends...mind whirling... my esophagus was shrinking. I could hardly breathe...so exhausted of my journey inward. Still a halfway journey... knees trembling... my mouth suddenly dried up...I needed to swallow a lump in my throat... helpless, I really was. The quest I trod... is not an easy one...the time has not yet come. Life was eating me up...months to complete... sickening...sleepless night...time was running out. With temper teetering on volatility...the experience ...made my blood boil ...fuming mad. My heart was so heavy, my chest churning and heaving...like a cup of hot tea. I almost gave up...everything was getting near... and everything near was turning into stone. The week past had been hell... and I could not even hear the whisper of God, I shed tears...precious little tears of hardship all wasted... as if the whole world has fallen on me... as if fighting the worst battle in life and ...my oil was consumed..."

At the top of the summit, the PINNACLE AND PLATEAU PHASE resounded with feelings of submission, sufficiency, and surmounting. "I have learned to accept the pain...a mind conditioning. I had to look in and study myself...I peeked, and I realized that letting go...detaching myself from all...emptying myself was necessary. I surrendered... renounced my pride...and transcend all... Malleable and tentative...constantly willing to change...l said to myself, '...take stock of your predicament... handle your anger right ... face the battle...take the bull by its horns, as a tiger...get out... unscathed.' Coming to the... last step... I am climbing...made me fight for worth. It was like moving through the hard veins of heavy mountains...like riding the waves... the ups and downs of writing. I have to...hit the target...like going on... a roller coaster ride with no delay of any kind... the journey has to move on...no turning back."

And then the PLUNGE PHASE vibrated with feelings of relief, release, and resoluteness. 


\begin{abstract}
"As if sloshed in the whirlpool...splashed by a bucket of water, things I needed to recover the lost strength ... providing the antidote. Behind those clouds is the sun shining brightly... lilies in the field... simple but full of colors... the most beautiful flower in the garden. My life would be shining again ...smooth sailing all along... memories...like starlight...the gloomy side made the other side brighter... as if I peeped a bit of heaven and all the worries...led to a deeper joy. I am... ready to be decoded and morphed...in my search for...the golden egg...a treasure. I see...a road map... lead me to the right path. I see... a big canvass... and I need to complete the picture... I see the stepping-stones... to a place of endless possibility."
\end{abstract}

Figure 1 elegantly portrays the sloping rise and fall of emotions/feelings in the lived experience of research anxiety, ie, ...moving through the hard veins of heavy mountains... last step of the ladder I am climbing .... a roller coaster ride with no delay of any kind...riding the waves...the ups and down of writing.

\section{Roots}

Recurring metaphors suggest that we as graduate students considered our research writing experience as an enormous TASK with a beginning and an end...accompanied by anxiety, faced with... turmoilof mixed emotions. Sharing work with an immediate panel of fellow students with the same assignment can become too much to bear. Some of us who took the course are members of a research center and some of our fellow students feared we have more exciting or more meaningful personal experiences to bring to the writing process and misconstrued or maybe misunderstood our mentor's editing as deep censorship and pure criticism. Some were vocal to the point of cynicism. They felt that writing is a competition, with us whom they believed had a richer store of writing material, not to mention the possibility of superior writing skills...feeling that they must pass a TEST...rooted...in not knowing their craft.

Many of us viewed research writing as a TRAVEL...a long journey ahead, ...have to move on...no turning back... a journey that is characterized by going up and sliding down... the ups and downs...like moving on the hard veins of heavy mountains... on a roller coaster ride...riding a wave...the last step of the ladder I am climbing.... a journey that requires overcoming seemingly insurmountable odds... enemy nowhere to find ...fight for worth....till my oil is consumed... a journey that is bound by TIME... and time was running out. For many, the research experience required a lot of reflecting...to engage in lots of THINKING... so exhausted of my journey inward...to look in and study myself...l took a peek...that part of me which I have not totally explored...my inner self soaring for its meaning.

Our tribulations are many and the difficulties have been pinpointed by some as related to perceived or actual inadequacies with the language...TONGUE, English is not my mother tongue, with forming ideas, in THOUGHT, if only I had superior IQ...in TEXT, I was not very certain about my capability in writing... in grammar...hoping that I could be rich in vocabulary... when I tried to develop a research TOPIC that is relevant, feasible, and researchable...a fiendish voice... whispered in my ears 'you'll never make it,' the TITLE I submitted was rejected... although I have tried to change it several times...l could not regain the interest I have lost... THREADS and THEMES, gone with the wind...in so many directions... disoriented... it seems that I...could never tie up the...loose ends...no TEMPLATE.

Difficulties of not being able to achieve focus, the TARGET ... hit the bull's eye...l did not know how to start this project...too proud to ask for help from anyone...everything seemed TENTATIVE...I really thought of quitting ... about giving up everything that I have started... but is quitting the best solution? I was... saying exactly the opposite of what I was feeling...it seemed so dark though the sun was shining brightly... the battle was there... but the enemy...nowhere to find.

Difficulties associated with the research and statistical TOOLS, this book for your evaluation instrument...after painstakingly researching for additional materials...revise... and remove it...l cannot seem to do anything right... 


\begin{abstract}
TECHNOLOGY, is the in thing...copies of the files...were not difficult to retrieve... but then...my diskette is missing the day before the defense...my encoder started to retype... and errors in my computer...the day before technical validation... a screeching exclamation sound... a dialog box flashing that the computer was low in resources.
\end{abstract}

Students suffering from writer's anxiety fear that judgment of their work is personal rather than performance-based, so that they tend to withdraw altogether from the idea of writing overall. This is usually most pronounced in an academic setting when students are so daunted by the idea of having their work judged that they will go to any length to avoid being looked upon as inferior and will essentially shut down. They will not write. Those who manage to go through the research writing experience reach the peak of their anxiety during the thesis defense...I felt I was in a TRIAL being interrogated... as if the world had fallen on me.

\section{Resolutions}

Given the right writing environment, a TRACK to follow, the researcher manages to overcome his fears. He realizes that no matter how hard the journey, the TRAVELER never journeys alone. He finds the TORCH, a research center perhaps that provides the right milieu....an education in research... behind those clouds is the sun shining brightly... like starlight at the end of the TUNNEL. The narratives echoed with portrayals of a companion on the journey, a friend, a mentor, an adviser, a supervisor, a TEACHER, better with the help of others... someone who would provide encouraging...comforting words... and support... a companion who would be the road map...constantly guiding... lead to the right TRAIL... to the right path.

The sine qua non for writing anxiety is that it can prevent students from writing to their maximal potential. Whatever the cause, by accepting the TRUTH that writer's anxiety does exist ... face the battle...take the bull by its horns... handle my anger right...the journey has to move on...no turning back, from whatever cause, whether from rules that can hold one back, whether from a misapprehension of what is being graded, from being unrealistic in thinking that other students might be better, or from an environment that might not be too favorable, the writer can overcome his anxiety. The best way research mentors can alleviate research writing anxiety is to know their students' THRESHOLDS, by recognizing their writing potentials...tension enveloped my body...paralyzing my creative soul...so they can work to adjust whenever possible. Writing anxiety is powerful but not impossible to overcome. By simply acknowledging its existence, mentors can provide the directions, the TRAJECTORY ... and lead their students to do just that. At the end of the journey, a prize awaits the traveler...the golden egg...a TREASURE...the realization...a chance to grow a soul...to complete the picture... in the canvass...and the realization and TRANSFORMATION, a development in the positive direction... a chance to grow a soul...decoded and morphed...from novice to expert...mastering an area of...life... embracing a different ethos

\section{DISCUSSION}

This paper presents the synthesis of a selection of academic storytelling in the form of narrative portrayals on anxiety and anger as emotions evoked during the research writing experience, its representations, roots, and resolutions as described by graduate students in a comprehensive university in the Philippines.

Evelyn [17] contended that "a narrative is a form of research and representation, which is inherently educational." She proposed further "that a hybrid form of academic poetic storytelling is capable of conveying both the subtleties of individual subjective experience and collective aspects of experience in concise and unique ways. "My fellow graduate students and myself were within a simulacrum, engaged and experiencing the same anger and anxiety at the same time, yet I must rise above the cacophony of figures of speech so that I can make sense of the whole experience. Minhha [18] critically encapsulates this research dilemma: "A conversation of 'us' with 'us' 
about 'them' as a conversation in which 'them' is silenced. 'Them' always stands on the other side of the hill, naked and speechless, barely present in its absence."

As graduate students during years of study at the university, we are frequently asked to demonstrate our knowledge through writing. Yet, a large number of us have difficulty composing text at a level required by the course. Research anxiety is a very common disorder among students in various academic settings as well as professionals in many different fields. It is a very real disorder that has received scant attention as a legitimate complaint. Other authors write about writers' block and other composing process problems, but their works were mainly written from an etic or outsider perspective. $[3,19]$. The limitation in some of the previous studies on research anxiety is the lack of a sufficiently emic perspective in the interaction. As an emotion/feeling-laden phenomenon, research writing anxiety that is written from an emic or insider perspective, as in this paper, best captures the essence of the phenomenon of research writing anxiety as co-experienced by the author and his classmates in a qualitative research writing course. The result-this paper-highlights rather than suppresses the similarities, tensions, and differences of our shared experience. Unlike other authors who write jointly or collaboratively to create prose poetry, [20] this paper was written solely by me, and my roles as a participant and autoethnographic researcher are fused.

\section{Anticipating character assessment instead of performance/product assessment}

Oftentimes students are so intimidated by the idea of having their work judged that they would go to any length to avoid being looked upon as inferior and will essentially shut down. They will not write. What is more damaging with this type of writing anxiety is that these students will most likely avoid seeking help from their instructor because they feel that the instructor does not like them personally. This reaction is easily misconstrued by teachers, who may conclude that the student is lazy, unmotivated, or maybe even unintelligent. Unfortunately, this scenario has far too much potential to end up affirming the writer's original fear, a form of negative feedback that ends up in a vicious cycle resulting in the student feeling increasingly inadequate and incompetent.

When a student's self-esteem decreases, they tend to abandon all assignments easily because it is preferable for some students to fail because they have exerted no effort at all as opposed to a bad mark that they believe is linked to preconceived and ill-gotten beliefs about their personalities. To assist the students in minimizing their writing anxiety, research mentors can introduce rubrics to the students prior to accomplishing writing tasks.[21].

\section{Self-efficacy in comparison with other students}

Sharing work with an immediate panel of fellow students with the same assignment becomes too much to bear. Because they fear that other students have more exciting or more meaningful personal experiences to bring to the writing process, many writers misunderstand the editing stage as deep censorship and base criticism.

Globally, English is the language that is used mostly in communication. Students do not want to write when they feel writing is a competition with other students that they believe have a richer store of writing material, not to mention the possibility of superior writing skills because of a facility with using English in research writing. Students who write better quality compositions have low levels of anxiety compared to their counterparts with higher levels of anxiety. Several authors, notably, Cheng [4,5], Jebriel, et al, [6] found a significant negative correlation between anxiety and the performance of students who use English as a Foreign Language (EFL) in research writing tasks. One of our classmates was an Indonesian who was an EFL student. As EFL students may place more emphasis on developing native-like proficiencies in comparison to their monolingual peers, they may experience higher levels of anxiety and lower levels of self-efficacy towards learning specific language skills.[22,23]. In the Philippines, English as a second language or L2 is taught as one of the required subjects until college years. Still, the majority of learners still exhibited problems and hitches in paragraph writing, more so in graduate research writing.[24,25]. Writing under time constraints was also found to have a detrimental effect resulting in writing anxiety. $[23,26,27]$. 


\section{Confinement to conventions, rules, and formats}

For those who lean towards research in the hard sciences, creative writing becomes an ordeal as they hang on to analytical discourse with its rigid IMRAD rules. 'Ruled' paper took on new meaning in the classroom. It meant 'ruled' as in a measuring stick, would my ideas measure up? Ruled as in following the rules, performing in a particular manner. Ruled as in reigned over, was there a central theme good enough to govern the entire paper? Cheng [5] noted however, that when freed from rigid rules, students might feel less writing anxiety. A research student should embrace qualitative research writing as a form of creative writing. It seems unnatural to compose argumentative or opinion essays without using "I think," "I believe," or "in my opinion." Using poetic inquiry as a methodological strategy structures the lived experience into poetic form. [28]. Lyric essays and poems thus function as a creative research act of revelation and intervention, and as a practice reliant upon image, language, and form, and exploring the voice and agency of the writer using metaphor, personification, simile, and analogy.

Toward this end, Qashoa [29] proposed the process approach to writing as an alleviating strategy. According to this approach, writing is looked at as a creative act requiring planning, editing, chunking, drafting, working in groups, peer correction, and getting feedback rather than setting students a writing topic and receiving it as a product for correction without any feedback or discussion during the writing process itself. In her doctoral dissertation, Kuhlthau [30] proposed that understanding uncertainty in the early stages of research writing leads to better tolerance of uncertainty. Awareness of the research process improved students' perception of the process and helped students understand and cope with the feelings of uncertainty, confusion, doubt, and frustration. Kracker [31,32] emphasized that Kuhlthau's ISP model includes awareness of (a) the stages of research; (b) the thoughts typical for each stage; and (c) the iteration in the stages.

\section{The writing environment}

Oftentimes students have difficulty developing their research writing when their space does not put them in the appropriate mood for writing. Depending on the student, one may discover that his/her writing flows freely when in an environment that promotes research writing, such as a research center. Others would argue that to take writing seriously and stay concentrated on the writing task at hand, they must be in an environment that promotes stringent guidelines to follow. There are, however, those students who would like to achieve a balance between the "very relaxed" and the "very strict and focused" environment. In such cases, students may find that a school's computer laboratory may be conducive to productive writing because a laboratory has a little of both atmospheres; on one hand, it creates a school-like setting because of its location, and on the other, it enables students to feel more at ease because they are not technically confined to the space or desk in an actual classroom. Unfortunately, it is impossible to please every single student. Therefore, someone may inevitably be at a disadvantage, which decreases their ability to write effectively.

\section{Implications for research mentoring}

Several years hence, I found myself mentoring other students in the qualitative research genre and I clearly understand the situation they find themselves in. The bottom line with writing anxiety is that it can prevent students from writing according to their ability. Whether it results from a misunderstanding of what is being graded, from constricting conventions, from unrealistically comparing themselves to other students, or from an uncomfortable environment, writer's anxiety is real, and it is debilitating. The best way that we can alleviate research writing anxiety, as research mentors, is to know our students and recognize their writing prowess and abilities. In this way, we can work to make accommodations whenever possible. Research anxiety is powerful but not impossible to overcome. Various affective, cognitive, linguistic, and pedagogical mitigating strategies can be employed. By simplyacknowledging its existence, we lead our students in the direction of doing just that...towards a transformational mindset to overcome research anxiety. 


\section{REFERENCES}

1. Leggo C. Writing lives is more than writing lines: postmodern perspectives on life writing. LangLit. 2000;2(2). Available from: http://dx.doi.org/10.20360/g2jw25

2. Daly J, Miller M. The empirical development of an instrument to measure writing apprehension. Res Teach English. 1975;9(3):242-9.

3. Hjortshoj K. Understanding Writing Blocks. New York, NY: Oxford University Press.; 2001.

4. Cheng YS. A measure of second language writing anxiety: Scale development and preliminary validation. J Second Lang Writ. 2004;13(4):313-35.

5. Cheng Y. EFL Students' Writing Anxiety: Sources and Implications. English Teach Learn. 2004;29(2):41-62.

6. Jebreil N, Azizifar A, Gowhary H, Jamalinesari A. A study on writing anxiety among Iranian EFL students. Int J Appl Linguist English Lit. 2015;4(2):68-72.

7. Sumara DJ. Fictionalizing acts: Reading and the making of identity. Theory into practice. 1998 Jun 1;37(3):203-10.

8. Rowling JK. Harry Potter and the sorcerer's stone. Arthur A. Levine; 1997.

9. Heidegger Ma. Being and time. SUNY Press; 2010.

10. Lahman MKE, Richard VM, Teman ED. ish: How to write poemish (research) poetry. Qual Inq. 2019;25(2):215-27.

11. Fitzpatrick $E$, Fitzpatrick K. What poetry does for us in education and research. In: Poetry, Method and Education Research. Abingdon, Oxon; New York, NY : Routledge, 2020.: Routledge; 2020. p. 1-18.

12. Glesne $C$. That rare feeling: Re-presenting research through poetic transcription. Qual Inq. 1997;3(2):202-21.

13. Canagarajah $S$, Lee E. Negotiating alternative discourses in academic writing: Risks with hybridity. 2014:59-99. In: Thesen L, Cooper L, editors. Risk in academic writing: Postgraduate students, their teachers and the making of knowledge. Bristol, Bufallo, Toronto: Multilingual Matters; 2014. p.59-99.

14. Chang W, Fukushima S. 'Your care and concern are my burden!': Accounting for the emic concepts of 'attentiveness' and 'empathy" in interpersonal relationships among Taiwanese females.' East Asian Pragmatics. 2017;2(1):1-23.

15. Anderson T, Fourie I. Collaborative autoethnography as a way of seeing the experience of caregiving as an information practice. In: In Proceedings of ISIC: the information behaviour conference. 2015.

16. Owen WF. Interpretive themes in relational communication. Quarterly Journal of Speech. 1984;70:274-87.

17. Evelyn D. Telling stories of research. Stud Educ Adults [Internet]. 2004;36(1):86-1 10. Available from: https://doi.org $/ 10.1080 / 02660830.2004 .11661489$

18. Minh-ha TT, Parmar P. Woman, native, other. Fem Rev [Internet]. 1990;36(Autumn):65-74. Available from: http:// www.jstor.org/stable/1395110

19. Rose M. When a Writer Can't Write: Studies in Writer's Block and Other Composing-Process Problems. New York, NY: The Guilford Press; 1985.

20. Hetherington $P$, Atherton C. Writing together: Conjunctive collaboration, scholarship and prose poetry. 2020;24(2): 1-18.

21. Arindra MY, Ardi P. The correlation between students' writing anxiety and the use of writing assessment rubrics. Learn J Lang Educ Acquis Res Netw. 2020;13(1):76-93.

22. Torres KM, Arrastia-Chisholm MC, Tackett S. Perceptions of writing anxiety and self-efficacy among spanish heritage language learners. J Hispanic High Educ. 2020;19(1):84-98.
23. Wahyuni D, Witri $O$, Marlina L. Writing Anxiety among Indonesian EFL College Students: Levels, Causes, and Coping Strategies. Ling Cult. 2019;13(1):67.

24. Kabigting RP, Gumangan AS, Vital DP, Villanueva ES V, Mosuela ES, Muldong FB, et al. Anxiety and writing ability of Filipino ESL learners. Int J Linguist Lit Trans/ [Internet]. 2020;3(7):55-67. Available from: www.al-kindipublisher. com/index.php/ijllt

25. Labicane GEM. Foreign language anxiety experiences of Filipino students across the four macro skills. Lang Lit J Linguist Lit Lang Teach. 2021;5(1):254-64.

26. El Shimi E. Second-language learners' writing anxiety: Types, causes, and teachers' perceptions. Department of Teaching English to Speakers of Other Languages at the American University in Cairo. 2017.

27. Ho M. Exploring writing anxiety and self-efficacy among EFL graduate students in Taiwan. High Educ Stud. $2015 ; 6(1): 24$.

28. Pelias RJ. Poeticizing the Everyday: Poetic Inquiry. In: The Creative Qualitative Researcher. 1 st Ed. London: Routledge; 2019. p.32.

29. Qashoa SHH. English Writing Anxiety: Alleviating Strategies. Procedia - Soc Behav Sci [Internet]. 2014;136:5965. Available from: http://dx.doi.org/10.1016/i. sbspro.2014.05.288

30. Kuhlthau CC. The library research process: case studies and interventions with high school seniors in advanced placement English classes using Kelly's theory of constructs. Rutgers The State University of New Jersey-New Brunswick; 1983.

31. Kracker J. Research anxiety and students' perceptions of research: An experiment. Part l. Effect of teaching Kuhlthau's ISP model. J Am Soc Inf Sci Technol. 2002;53(4):282-94.

32. Kracker J, Wang P. Research anxiety and students' perceptions of research: An experiment. Part II. Content analysis of their writings on two experiences. J Am Soc Inf Sci Technol. 2002;53(4):295-307.

(c) (D) Open Access This article is licensed under a

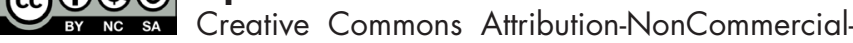
ShareAlike 4.0 International License, which permits use, share - copy and redistribute the material in any medium or format, adapt - remix, transform, and build upon the material, as long as you give appropriate credit, provide a link to the license, and indicate if changes were made. You may do so in any reasonable manner, but not in any way that suggests the licensor endorses you or your use. You may not use the material for commercial purposes. If you remix, transform, or build upon the material, you must distribute your contributions under the same license as the original. You may not apply legal terms or technological measures that legally restrict others from doing anything the license permits. The images or other third party material in this article are included in the article's Creative Commons license, unless indicated otherwise in a credit line to the material. If material is not included in the article's Creative Commons license and your intended use is not permitted by statutory regulation or exceeds the permitted use, you will need to obtain permission directly from the copyright holder. To view a copy of this license, visit https://creativecommons.org/licenses/by-nc-sa/4.0/. 